\title{
THE EIDER DUCK AND THE SPOONBILL IN THE NETHERLANDS
}

\author{
By G. J. VAN OoRDT \\ The Eider
}

The first record of the eider breeding in the Netherlands was a report in 1906 by the German ornithologist, O. Leege. He gave the site as the island of Vlieland, north-east of Texel. Few further such observations were made until 1925 when I myself estimated the total number of breeding females on Vlieland as ten, chiefly in the western part. Since then protective measures have been taken. A keeper has regularly visited the reserved area, eggs have been protected from herring gulls as far as possible, and when a breeding bird has accidentally been flushed, her eggs have been covered up with down.

Thanks to these measures and to the quantity of food available - there are extensive mussel banks in the neighbouring Waddensea-the eiders increased. In 1926 the number of observed breeding females was 5 , in 1928,16 ; in 1931, 25-30 ; in 1934,134 ; in 1935 , about 200 ; but the true number was, of course, much greater. In 1936 I estimated the number of breeding females as 300 ; by 1940 it was still more. In spite of the heavy toll taken of the eider on Vlieland by the Germans during the war, its numbers there remained much the same. It also established two new colonies. One of these is on the northern part of Texel where more than fifty pairs now breed; the other is on the Boschplaat, the large sanctuary in the eastern part of Terschelling; here by 1954 the eiders had increased to more than 300 pairs. Some nests have also been found recently on the islands of Ameland and Schiermonnikoog.

The most spectacular increase of this species has, however, taken place in its old breeding haunt, Vlieland, where it now breeds not only in the protected area, the so-called Meeuwenduinen, but all over the island. In 1954 I estimated the number of breeding females at 2,000. This was based on the number of nests found, the number of females with young and the number of adult males counted on the mudflats. Thus we can safely say that Vlieland now possesses one of the largest breeding colonies of eiders in western Europe. Moreover, the Dutch colonies form the most southerly ones on the North Sea coasts. Whether they are also the most southerly colonies on this side of the Atlantic I do not know, because recent information from the coast of Brittany is lacking. 


\section{The Spoonbill}

In 1905 the "Vereeniging tot Behoud van Natuurmonumenten in Nederland" (Society for the promotion of nature reserves in the Netherlands) was founded with the object of purchasing the "Naardermeer", the famous breeding place near Amsterdam of spoonbills, purple herons and other marsh birds. At that time the only other colony of spoonbills in the Netherlands was at the "Zwanewater" (Swanlake), a dune lake near Callantsoog, in the province of North Holland. Due to protection the spoonbills gradually increased in both colonies. From 1908-1912 the number of pairs in the Naardermeer was about twenty-five; from 1916-1922 -it increased to about sixty. At the beginning of the thirties at least two hundred pairs were breeding in the Zwanewater.

In 1910,1921 and 1923 the spoonbill tried to nest at the Muy, a beautiful dune lake on the island of Texel, but without much success. From 1924-1930 a flock of ten to twenty nonbreeding birds were usually present here during the summer months. In 1931 it again tried to breed in the Muy but the only nest was disturbed.

In 1933, however, thanks to protective measures, the spoonbill founded a permanent breeding colony in the Muy. Starting with five nests in 1933 the colony, by 1936, contained more than forty pairs. Just before the war it was about 100. The number during the war is not known but afterwards it increased gradually -being more than 110 in 1950 and about 150 in 1954 .

In the meantime the nests in the Naardermeer had increased also. Exact figures are not available, for the birds are disturbed as little as possible, but there are now more than 150 breeding pairs. The same holds good for the colony in the Zwanewater, which is now estimated at more than 200 pairs.

In 1953 a solitary nest was built but abandoned on the Geul, another dew lake in Texel. But in 1954, notwithstanding the fact that the sandflats to the south are used as a bombing range, about five nests were built and several young were hatched. This new colony, like the others, is protected by the State Forest Department. Let us hope that it will thrive in our country as have the other settlements of this beautiful and interesting bird. 